\title{
Student Learning in Public and Private Primary Schools in Madagascar
}

\author{
Gérard Lassibille \\ Institut de Recherche sur l'Economie de l'Education, Centre National de la \\ Recherche Scientifique
}

Jee-Peng Tan

World Bank

\section{Introduction}

Primary education in developing countries is, in many ways, the core of the schooling system. It serves the greatest number of students, absorbs the largest share of total spending on education, and builds the bedrock for human capital development. Typically, therefore, the performance of primary education attracts policy debate both in terms of the system's coverage at this level of schooling and its ability to produce student learning. Indeed, to some observers, the extent to which pupils master the basic skills of reading, writing, and arithmetic may well be a more relevant benchmark for evaluating a school system's performance than the sheer volume of enrollments.

This article examines the progress of primary education in Madagascar. While the focus is on student learning, a few facts about the system's coverage set the context for this study. The country has an extensive network of schools, with about a quarter of them in a private sector composed of largely selffinancing establishments. In 1998, about one-fifth of the pupils attended private schools, a much larger share than in most countries at Madagascar's level of economic development. The generous availability of schools combines with a strong social demand for schooling to produce high rates of entry to first grade (about $80 \%$ of each birth cohort in 1998). Unfortunately, the good start is not sustained at subsequent grades, as only $33 \%$ of the first-graders eventually reach the end of the 5 -year primary cycle at present $(28 \%$ in public schools as compared with $53 \%$ in the private sector). Furthermore, the rate of repetition is very high, averaging $31 \%$ on average in 1998 (34\% in public schools as compared with $19 \%$ in the private sector). ${ }^{1}$ 
With regard to student learning, international comparisons place Madagascar in a relatively favorable light. According to results from the 1999 Monitoring Learning Achievement (MLA) study, sponsored by UNESCO in 18 mostly African countries, Malagasy fourth-graders fared reasonably well among children from the 11 countries for which data are currently available. ${ }^{2}$ The favorable ranking is consistent with the results from surveys sponsored during the mid- to late-1990s by the Conférence des Ministres de l'Education des Pays Ayant le Français en Partage (CONFEMEN) in five African countries where common tests were administered to second- and fifth-graders. ${ }^{3}$

While the cross-country comparisons are salutary, test scores remain low in absolute terms, with the sample pupils answering, on average, only half of their test items correctly. Furthermore, given the poor survival rates in the primary cycle, Madagascar's favorable ranking relative to other countries, particularly for the higher grades, refers to a somewhat selective and privileged group of children. The challenge facing policy makers is therefore enormous: how to maintain (or indeed, improve) learning outcomes while making efforts to ensure that all children reach the end of the cycle.

To help inform the policy dialogue, this article looks more closely into the production of student learning across schools within Madagascar based on the data from the CONFEMEN survey mentioned above. The survey for Madagascar was fielded during the period 1997-98 and involved pupils from a total of about 115 public and private schools. Beyond documenting the aggregate differences across sectors, we evaluate the extent to which differences across schools, particularly between those in the public and private sectors, are associated with pupils' socioeconomic background, differences in school inputs, and gaps across schools in managerial effectiveness. The available data also permitted an assessment of the relation between school funding and student learning. In addressing these questions, this article contributes to the growing literature on the determinants of student achievement, particularly on the relative effectiveness of public and private schools in developing countries. $^{4}$

The article is structured as follows: Section II presents our analytical framework for estimating student achievement gaps between the public and private sectors; Section III describes the data set; Section IV presents the empirical results; and Section V summarizes the main findings and conclusions.

\section{Analytical Framework}

Following common practice in the economics of education, students' performance is modeled as a function of pupils' personal characteristics, including initial learning at the start of the school year and family background; school and classroom conditions, including characteristics of the teacher; and type of school attended. ${ }^{5}$ For the $i$ th pupil, performance $\left(A_{i}\right)$ is given by

$$
A_{i}=\beta \boldsymbol{X}_{i}+\alpha S_{i}+\varepsilon_{i},
$$

where $\boldsymbol{X}$ is a vector of achievement determining variables; $S$ is the type of 
school attended by the student, private $\left(S_{i}=1\right)$ or not $\left(S_{i}=0\right)$; and $\varepsilon$ is an error term. ${ }^{6}$

If students in a particular school type differ systematically in some characteristics that are not explicitly represented by the variables in $X$, then the estimation of the sector effect through ordinary least squares (OLS) would be biased. One source of this possibility is that the students who attend a particular type of school (or their families) may share, for example, a preference for the values that receive specific emphasis in those schools. To take into account this selection effect, we estimate a treatment effect model using the Heckman two-step method to correct for selection bias. ${ }^{7}$

To elaborate, we estimate in the first step a sector of schooling-choice model by the probit maximum likelihood method and generate the following selection terms for each alternative:

$$
\begin{gathered}
\lambda_{1}=\frac{\phi(\mathrm{Z} \gamma)}{\Phi(\mathrm{Z} \gamma)} \text { if } S_{i}=1, \\
\lambda_{0}=\frac{\phi(\mathrm{Z} \gamma)}{1-\Phi(\mathrm{Z} \gamma)} \text { if } S_{i}=0,
\end{gathered}
$$

where $\phi$ and $\Phi$ are, respectively, the standard normal density and cumulative distribution functions, and $\gamma$ is the parameter vector associated with the school choice determining variables. In the second stage, we estimate the following regression:

$$
A_{i}=\beta \boldsymbol{X}_{i}+\alpha S_{i}-\sigma\left[\lambda_{1} S_{\mathrm{i}}-\lambda_{0}\left(1-S_{i}\right)\right]+u_{i} .
$$

Ignoring for the moment the effects of selection bias, the advantage of attending a private school is simply computed as follows:

$$
E\left(A_{i} / \mathrm{S}_{\mathrm{i}}=1\right)-E\left(A_{i} / S_{i}=0\right)=\hat{\beta} .
$$

The result measures the unconditional advantage of attending a private school (unconditional because it takes into account only the impact of the observed characteristics on performance) and ignores the impact of selection bias associated with the school-choice process.

We can also compute the conditional achievement advantage by incorporating the effects of selection bias in the calculation. Specifically, the predicted achievement of a pupil in a public and private school, respectively, after taking into account possible selection bias, is given by

$$
\begin{gathered}
E\left(A_{i} / S_{i}=1\right)=\hat{\beta} \boldsymbol{X}_{i}+\hat{\alpha} S_{i}-\hat{\sigma} \hat{\lambda}_{1}, \\
E\left(A_{i} / S_{i}=0\right)=\hat{\beta} \boldsymbol{X}_{i}+\hat{\sigma} \hat{\lambda}_{0} .
\end{gathered}
$$


The conditional effect of the private sector on achievement is given by the difference between these two equations:

$$
E\left(A_{i} / S_{i}=1\right)-E\left(A_{i} / S_{i}=0\right)=\hat{\alpha}+\hat{\sigma}\left(\hat{\lambda}_{0}-\hat{\lambda}_{1}\right) .
$$

By choosing appropriate variables in the regression specification, we can estimate the impact of resource endowment and managerial efficiency on schools' performance. Specifically, when $\boldsymbol{X}$, the vector of factors postulated to influence test scores, includes only a student's test scores from a previous grade and his or her personal and family characteristics, ${ }^{8}$ the performance advantage of a private school represents the totality of school effects on student performance arising from the combined influence of differences in the tangible schooling environment as reflected, for example, by class size, staff qualification, availability of textbooks, condition of school facilities, the school head's management style, and so on, and differences in the effectiveness with which the available inputs are managed to promote student learning.

Alternatively, when $\boldsymbol{X}$ is expanded to include the variables representing the tangible schooling environment, the performance advantage would then capture the impact on student achievement of differences of intangible factors such as managerial effectiveness (as well as unmeasured inputs) - at both the classroom and school levels-beyond that attributable to the personal and family attributes and tangible aspects of the schooling environment. Managerial effectiveness here corresponds to what Leibenstein refers to as $x$-efficiency factors, which relate to such influences on student achievement as incentives, motivation, and other organizational and cultural dimensions of the schooling context. ${ }^{9}$

\section{The Data}

The data come from the 1997-98 survey for Madagascar sponsored by the Programme d'Analyse des Systèmes Educatifs de la CONFEMEN (PASEC), which gathered information on separate samples of some 1,900 pupils in grades 2 and 5 in a total of about 120 public and private schools. The survey is particularly suitable for the analysis attempted here because it tested pupils both at the beginning and the end of the school year, making it possible to model the determinants of learning as a dynamic process over the course of a school year during which the impact of the learning environment as well as other factors can be assessed.

In both grades, 20 pupils per classroom were tested in French and mathematics in about 25 private schools and 90 public schools. The survey is composed of three questionnaires: students, teacher, and school director. ${ }^{10}$ The student-level data contain information on age, gender, repetition status, education level of the parents, household wealth, whether or not the child speaks only Malagasy at home, and whether or not the child receives parental help with homework. The teacher data files contain detailed information on age, gender, work experience, formal qualification, exposure to teacher training, 
and class size. The school director questionnaire consists mainly of schoollevel questions about school facilities.

The data are, on the whole, of reasonable quality. Information on some of the class-level variables tends to be less complete than student-level data, however, either because teachers did not complete the survey forms or because they gave irrelevant answers. ${ }^{11}$ In estimating achievement models, we address the missing data problem by performing zero-order or modified zero-order regressions. ${ }^{12}$ These problems notwithstanding, the available data remain sufficiently rich for our analysis.

Table 1 presents the summary statistics for our dataset, with means and standard deviations of the variables shown for the entire sample as well as by school type. Several features in the data are noteworthy. In both grades, students in private schools tend to perform better than their public school counterparts, with outgoing test scores-the mean across the two subjects-higher by 0.4 and 0.7 of a standard deviation in grades 2 and 5, respectively. ${ }^{13}$ The variance in scores is somewhat smaller in the public sector, implying greater homogeneity in performance in public schools. One of the main issues addressed below is the extent to which this apparent difference in performance between public and private schools persists after controlling for selectivity biases in the data and for differences across schools in student characteristics and school inputs.

The two types of school serve different clientele. Students attending private school are younger and are less likely to have repeated grades as compared with their public school counterparts. As reflected by the index of family wealth, they also come from wealthier families than do public school students. ${ }^{14}$ Finally, students are divided equally by gender, and girls are as likely to attend a private school as boys.

Turning now to class-level characteristics, we note that, as compared with public schools, schools in the private sector operate, on average, with smaller pupil-teacher ratios in grade 2 and higher ratios in grade 5. Public school teachers tend to be have more years of experience: depending on grade, the advantage may range between 5 and 10 years. They tend, however, to have fewer years of formal schooling, particularly among the second-grade teachers; they also have less exposure to preservice training, with a shortfall of between 1.6 and 2.0 months of training, depending on the grade. Finally, in terms of the availability of pedagogical and material resources, wide differences exist between public and private schools: in private schools, a larger proportion of students have access to math and French textbooks, and the quality of the physical facilities of the classroom are, on average, better in the private sector than in the public sector. ${ }^{15}$

\section{Empirical Results}

Following the analytical framework described in Section II, we present the empirical results in three parts: the correlates of learning outcomes in grades 2 and 5, the implications of the regression estimates regarding the efficiency 
TABLE 1

Sample Characteristics of Pupils and Schools

\begin{tabular}{|c|c|c|c|c|c|c|}
\hline \multirow[b]{2}{*}{ Characteristic } & \multicolumn{2}{|c|}{ TOTAL } & \multicolumn{2}{|c|}{$\begin{array}{l}\text { Private } \\
\text { Schools }\end{array}$} & \multicolumn{2}{|c|}{$\begin{array}{l}\text { Public } \\
\text { SchoOLS }\end{array}$} \\
\hline & Mean & $\mathrm{SD}$ & Mean & $\mathrm{SD}$ & Mean & SD \\
\hline \multicolumn{7}{|l|}{ Grade-2 sample: } \\
\hline Outgoing test score ${ }^{a}$ & 0 & 1.00 & .31 & .98 & .09 & .99 \\
\hline Incoming test score ${ }^{a}$ & 0 & 1.00 & .33 & 1.04 & -.10 & .97 \\
\hline Girl & .51 & .50 & .51 & .50 & .50 & .50 \\
\hline Age (in years) & 8.44 & 1.46 & 7.65 & 1.39 & 8.68 & 1.39 \\
\hline Repeater & .54 & .50 & .38 & .49 & .58 & .49 \\
\hline Speaking only Malagasy at home & .71 & .45 & 69 & .46 & .72 & .45 \\
\hline $\begin{array}{l}\text { Pupil receiving help from parents for } \\
\text { homework }\end{array}$ & .72 & .47 & .69 & .45 & .73 & .48 \\
\hline Index of family wealth $\mathrm{h}^{\mathrm{b}}$ & & & & & & \\
\hline Pupil with math or reading textbook & .66 & .45 & .71 & .45 & .64 & .46 \\
\hline Class size & 49.02 & 24.49 & 47.80 & 15.54 & 49.36 & 26.45 \\
\hline Teacher experience (in years) & 14.31 & 8.95 & 6.48 & .26 & 16.49 & 7.93 \\
\hline Initial training of teacher (in years) & 10.15 & 1.92 & 10.88 & 2.80 & 9.94 & 1.55 \\
\hline $\begin{array}{l}\text { Preservice training of teacher (in } \\
\text { months) }\end{array}$ & 4.38 & 5.90 & 5.68 & 7.20 & 4.02 & 5.48 \\
\hline Index of classroom conditions ${ }^{\mathrm{c}}$ & 100.22 & 9.46 & 101.74 & 8.64 & 99.79 & 9.68 \\
\hline Private sector & .22 & .41 & 1.00 & 0 & 0 & 0 \\
\hline Number of pupils & 1,993 & & 461 & & 1,532 & \\
\hline Number of classrooms & 115 & & 25 & & 90 & \\
\hline \multicolumn{7}{|l|}{ Grade-5 sample: } \\
\hline Outgoing test score ${ }^{\mathrm{a}}$ & 0 & 1.00 & .54 & 1.02 & -.17 & .93 \\
\hline Incoming test score ${ }^{a}$ & 0 & 1.00 & .54 & .85 & -.17 & .98 \\
\hline Girl & .55 & .50 & .55 & .50 & .55 & .50 \\
\hline Age (in years) & 12.08 & 1.54 & 11.24 & 1.51 & 12.34 & 1.45 \\
\hline Repeater & .66 & .47 & .49 & .50 & .71 & .45 \\
\hline Speaking only Malagasy at home & .73 & .44 & .70 & .46 & .74 & .44 \\
\hline $\begin{array}{l}\text { Pupil receiving help from parents for } \\
\text { homework } \\
\text { Index of family wealth }\end{array}$ & .53 & .50 & 62 & .49 & .50 & .50 \\
\hline Pupil with math or reading textbook & .81 & .24 & .84 & .19 & .80 & .25 \\
\hline Class size & 36.85 & 13.94 & 46.17 & 15.40 & 34.19 & 12.35 \\
\hline Teacher experience (in years) & 15.58 & 9.26 & 11.17 & 8.90 & 16.84 & 9.02 \\
\hline Initial training of teacher (in years) & 10.76 & 5.37 & 13.71 & 10.64 & 9.92 & 1.60 \\
\hline $\begin{array}{l}\text { Preservice training of teacher (in } \\
\text { months) }\end{array}$ & 4.09 & 5.10 & 5.15 & 6.29 & 3.79 & 4.70 \\
\hline Index of classroom conditions $\mathrm{s}^{\mathrm{c}}$ & 100.45 & 9.12 & 99.80 & 9.68 & 100.64 & 9.01 \\
\hline Private sector & .22 & .78 & 1.00 & 0 & 0 & 0 \\
\hline Number of pupils & 1,900 & & 448 & & 1,452 & \\
\hline Number of classrooms & 108 & & 24 & & 84 & \\
\hline
\end{tabular}

${ }^{a}$ Scores refer to the percentage of test items correctly answered and are expressed in units of standard deviation from the mean (which has itself been recalibrated to zero in order to facilitate interpretation).

${ }^{\mathrm{b}}$ See $\mathrm{n} .14$ for an explanation of the construction of this index.

${ }^{\mathrm{c}}$ See $\mathrm{n}$. 15 for an explanation of the construction of this index. 
of the schooling process in the private and public primary schools, and a closer look at student achievement across public schools.

\section{A. Correlates of Learning Outcomes}

We first estimate a school-choice model, the results of which are used to correct for selection bias in the achievement regressions. The probit estimates appearing in table A1 show the probability that a student attends a private school. The regression model includes the following explanatory variables: personal characteristics of the student, index of family wealth, and the relative supply of the various types of schools in the student's home district, as proxied by the percentage distribution of private schools in the student's home district. ${ }^{16}$

The results confirm that private and public schools serve systematically different clienteles. Older students are more likely to choose public schools, and students from better-off families are more likely to attend private schools. The results also point to the role of supply factors in school-choice behavior. Not surprisingly, the probability of attending a private school increases with its relative supply in the home district.

We turn now to the results pertaining to student achievement in mathematics and French. The regression results for the second-grade sample appear in table 2, which presents estimates for two models estimated in two different ways, namely, with and without using school inputs as separate regressors and by ordinary least squares (OLS) and controlling for selection bias. Similar regression results for the fifth-grade sample are reported in table 3.

As expected, the regression results for both the second- and fifth-grade samples confirm the importance of initial test scores as a determinant of yearend achievement. Learning involves a cumulative process, so a strong foundation in the early grades is critical for performance in subsequent years. Children from disadvantaged backgrounds, however, typically start their school year already handicapped in this regard. For example, second-graders in the sample who come from homes where only Malagasy is spoken score about 0.05 of a standard deviation below the sample mean on the combined mathematics and French tests as compared with 0.02 of a standard deviation above the mean among those who come from families where French is spoken as well.

With regard to the other influences on the progress in learning during the school year, the regression results conform to the expected pattern: what matters are the quality of a child's home environment, access to textbooks, the quality of the physical facilities of the classroom, as well as the type of school attended. Interestingly, a teacher's exposure to preservice training has no impact for either grades 2 or 5. One possible explanation is that those without preservice training find other ways to compensate for this gap in their professional profile (e.g., through school-based mentoring arrangements); another is that existing preservice teacher training programs are ineffective in teacher preparation. Among fifth-graders, a teacher's level of formal education 
TABLE 2

Correlates of Second-Graders' Combined Scores in Mathematics and French, MADAGASCAR, 1997-98

\begin{tabular}{|c|c|c|c|c|}
\hline \multirow[b]{2}{*}{ ChaRACTERISTIC } & \multicolumn{2}{|c|}{$\begin{array}{l}\text { EXCLUDING SCHOOL } \\
\text { INPUTS AS REGRESSORS }\end{array}$} & \multicolumn{2}{|c|}{$\begin{array}{l}\text { INCLUDING SCHOOL } \\
\text { INPUTS AS REGRESSORS }\end{array}$} \\
\hline & OLS & $\begin{array}{l}\text { Controlling } \\
\text { for Selectivity }\end{array}$ & OLS & $\begin{array}{l}\text { Controlling } \\
\text { for Selectivity }\end{array}$ \\
\hline Intercept & $\begin{array}{l}.080 \\
(.64)\end{array}$ & $\begin{array}{l}.073 \\
(.59)\end{array}$ & $\begin{array}{l}-1.242 \\
(4.37)^{* *}\end{array}$ & $\begin{array}{l}-1.164 \\
(4.12)^{* *}\end{array}$ \\
\hline Incoming test score & $\begin{array}{c}.551 \\
(28.53)^{* *}\end{array}$ & $\begin{array}{c}.544 \\
(28.11)^{* *}\end{array}$ & $\begin{array}{c}.548 \\
(28.07)^{* *}\end{array}$ & $\begin{array}{c}.541 \\
(27.66)^{* *}\end{array}$ \\
\hline Girl & $\begin{array}{c}.079 \\
(2.15)^{*}\end{array}$ & $\begin{array}{c}.087 \\
(2.37)^{*}\end{array}$ & $\begin{array}{r}.067 \\
(1.83)\end{array}$ & $\begin{array}{c}.073 \\
(2.02)^{*}\end{array}$ \\
\hline Age (in years) & $\begin{array}{r}.019 \\
(1.37)\end{array}$ & $\begin{array}{c}.067 \\
(4.02)^{* *}\end{array}$ & $\begin{array}{r}.019 \\
(1.37)\end{array}$ & $\begin{array}{l}.058 \\
(3.47)^{* *}\end{array}$ \\
\hline Repeater & $\begin{array}{l}-.058 \\
(1.50)\end{array}$ & $\begin{array}{l}-.054 \\
(1.41)\end{array}$ & $\begin{array}{l}-.053 \\
(1.38)\end{array}$ & $\begin{array}{l}-.052 \\
(1.35)\end{array}$ \\
\hline $\begin{array}{l}\text { Pupil speaks only Malagasy } \\
\text { at home }\end{array}$ & $\begin{array}{l}-.199 \\
(3.13)^{* *}\end{array}$ & $\begin{array}{l}-.164 \\
(2.58)^{* *}\end{array}$ & $\begin{array}{l}-.161 \\
(2.47)^{*}\end{array}$ & $\begin{array}{l}-.138 \\
(2.12)^{*}\end{array}$ \\
\hline $\begin{array}{l}\text { Pupil receives help from } \\
\text { parents for homework }\end{array}$ & $\begin{array}{l}.033 \\
(.78)\end{array}$ & $\begin{array}{l}.017 \\
(.39)\end{array}$ & $\begin{array}{l}.027 \\
(.62)\end{array}$ & $\begin{array}{l}.017 \\
(.39)\end{array}$ \\
\hline $\begin{array}{l}\text { Pupil has math or reading } \\
\text { textbook }\end{array}$ & & & $\begin{array}{c}.141 \\
(3.36)^{* *}\end{array}$ & $\begin{array}{l}.129 \\
(3.10)^{* *}\end{array}$ \\
\hline Class size & & & $\begin{array}{l}-.002 \\
(2.20)^{*}\end{array}$ & $\begin{array}{l}-.001 \\
(1.21)\end{array}$ \\
\hline $\begin{array}{l}\text { Teacher experience (in } \\
\text { years) }\end{array}$ & & & $\begin{array}{l}.002 \\
(.64)\end{array}$ & $\begin{array}{r}-.001 \\
(.41)\end{array}$ \\
\hline $\begin{array}{l}\text { Initial training of teacher } \\
\text { (in years) }\end{array}$ & & & $\begin{array}{l}.002 \\
(.63)\end{array}$ & $\begin{array}{l}.002 \\
(.82)\end{array}$ \\
\hline $\begin{array}{l}\text { Preservice training of } \\
\text { teacher (in months) }\end{array}$ & & & $\begin{array}{r}.011 \\
(1.09)\end{array}$ & $\begin{array}{r}.014 \\
(1.36)\end{array}$ \\
\hline $\begin{array}{l}\text { Index of classroom } \\
\text { conditions }^{\mathrm{a}}\end{array}$ & & & $\begin{array}{c}.011 \\
(5.30)^{* *}\end{array}$ & $\begin{array}{c}.010 \\
(4.79)^{* *}\end{array}$ \\
\hline Private school & $\begin{array}{c}.178 \\
(3.86)^{* *}\end{array}$ & $\begin{array}{c}.734 \\
(6.51)^{* *}\end{array}$ & $\begin{array}{c}.161 \\
(2.96)^{* *}\end{array}$ & $\begin{array}{c}.604 \\
(5.18)^{* *}\end{array}$ \\
\hline$\lambda$ & & $\begin{array}{c}.369 \\
(5.35)^{* *}\end{array}$ & & $\begin{array}{c}.314 \\
(4.30)^{* *}\end{array}$ \\
\hline Adjusted $R^{2}$ & .34 & .35 & .35 & .36 \\
\hline Number of observations & 1,993 & 1,993 & 1,993 & 1,993 \\
\hline
\end{tabular}

SourcE.-This table is based on data from the 1997-98 PASEC survey for Madagascar. NoTE.-The figures in parentheses are the robust $t$-statistics.

${ }^{a}$ See $\mathrm{n} .15$ for an explanation of the construction of this index.

* Significant at the $5 \%$ level.

** Significant at the $1 \%$ level. 
TABLE 3

Correlates of Fifth-Graders' Combined Scores in Mathematics and French, MADAGASCAR, 1997-98

\begin{tabular}{|c|c|c|c|c|}
\hline \multirow[b]{2}{*}{ ChaRACTERISTIC } & \multicolumn{2}{|c|}{$\begin{array}{l}\text { EXCLUDING SCHOOL } \\
\text { INPUTS AS REGRESSORS }\end{array}$} & \multicolumn{2}{|c|}{$\begin{array}{l}\text { INCLUDING SCHOOL } \\
\text { INPUTS AS REGRESSORS }\end{array}$} \\
\hline & OLS & $\begin{array}{l}\text { Controlling } \\
\text { for Selectivity }\end{array}$ & OLS & $\begin{array}{l}\text { Controlling } \\
\text { for Selectivity }\end{array}$ \\
\hline Intercept & $\begin{array}{l}1.234 \\
(6.90)^{* *}\end{array}$ & $\begin{array}{l}1.150 \\
(6.33)^{* * *}\end{array}$ & $\begin{array}{c}.619 \\
(2.08)^{*}\end{array}$ & $\begin{array}{r}.510 \\
(1.65)\end{array}$ \\
\hline Incoming test score & $\begin{array}{c}.403 \\
(15.49)^{* *}\end{array}$ & $\begin{array}{c}.396 \\
(15.09)^{* *}\end{array}$ & $\begin{array}{c}.400 \\
(15.21)^{* *}\end{array}$ & $\begin{array}{c}.395 \\
(14.88)^{* *}\end{array}$ \\
\hline Girl & $\begin{array}{r}.064 \\
(1.58)\end{array}$ & $\begin{array}{r}.070 \\
(1.75)\end{array}$ & $\begin{array}{r}.063 \\
(1.59)\end{array}$ & $\begin{array}{r}.069 \\
(1.72)\end{array}$ \\
\hline Age (in years) & $\begin{array}{l}-.069 \\
(4.59)^{* *}\end{array}$ & $\begin{array}{l}-.042 \\
(2.23)^{*}\end{array}$ & $\begin{array}{l}-.064 \\
(4.34)^{* *}\end{array}$ & $\begin{array}{l}-.042 \\
(2.21)^{*}\end{array}$ \\
\hline Repeater & $\begin{array}{l}-.094 \\
(2.13)^{*}\end{array}$ & $\begin{array}{l}-.087 \\
(1.98)^{*}\end{array}$ & $\begin{array}{l}-.083 \\
(1.88)\end{array}$ & $\begin{array}{l}-.077 \\
(1.74)\end{array}$ \\
\hline $\begin{array}{l}\text { Pupil speaks only Malagasy } \\
\text { at home }\end{array}$ & $\begin{array}{l}-.212 \\
(3.35)^{* *}\end{array}$ & $\begin{array}{l}-.203 \\
(3.25)^{* *}\end{array}$ & $\begin{array}{l}-.189 \\
(2.99)^{* *}\end{array}$ & $\begin{array}{l}-.184 \\
(2.93)^{* *}\end{array}$ \\
\hline $\begin{array}{l}\text { Pupil receives help from } \\
\text { parents for homework }\end{array}$ & $\begin{array}{l}.037 \\
(.93)\end{array}$ & $\begin{array}{l}.035 \\
(.88)\end{array}$ & $\begin{array}{r}.045 \\
(1.12)\end{array}$ & $\begin{array}{r}.044 \\
(1.10)\end{array}$ \\
\hline $\begin{array}{l}\text { Pupil has math or reading } \\
\text { textbook }\end{array}$ & & & $\begin{array}{c}.113 \\
(2.15)^{*}\end{array}$ & $\begin{array}{c}.111 \\
(2.10)^{*}\end{array}$ \\
\hline Class size & & & $\begin{array}{l}-.008 \\
(4.47)^{* * *}\end{array}$ & $\begin{array}{l}-.007 \\
(4.28)^{* *}\end{array}$ \\
\hline $\begin{array}{l}\text { Teacher experience (in } \\
\text { years) }\end{array}$ & & & $\begin{array}{c}.007 \\
(2.55)^{*}\end{array}$ & $\begin{array}{c}.007 \\
(2.42)^{*}\end{array}$ \\
\hline $\begin{array}{l}\text { Initial training of teacher } \\
\text { (in years) }\end{array}$ & & & $\begin{array}{r}-.003 \\
(.77)\end{array}$ & $\begin{array}{l}-.005 \\
(1.02)\end{array}$ \\
\hline $\begin{array}{r}\text { Preservice training of } \\
\text { teacher (in months) }\end{array}$ & & & $\begin{array}{l}.003 \\
(.96)\end{array}$ & $\begin{array}{r}.003 \\
(1.16)\end{array}$ \\
\hline $\begin{array}{l}\text { Index of classroom } \\
\text { conditions }^{\mathrm{a}}\end{array}$ & & & $\begin{array}{c}.007 \\
(3.29)^{* *}\end{array}$ & $\begin{array}{c}.007 \\
(3.41)^{* *}\end{array}$ \\
\hline Private school & $\begin{array}{c}.311 \\
(5.93)^{* *}\end{array}$ & $\begin{array}{c}.645 \\
(4.40)^{* *}\end{array}$ & $\begin{array}{c}.454 \\
(7.08)^{* *}\end{array}$ & $\begin{array}{c}.729 \\
(4.94)^{* *}\end{array}$ \\
\hline$\lambda$ & & $\begin{array}{c}.211 \\
(2.44)^{*}\end{array}$ & & $\begin{array}{c}.178 \\
(2.06)^{*}\end{array}$ \\
\hline Adjusted $R^{2}$ & .27 & .27 & .29 & .29 \\
\hline Number of observations & 1,900 & 1,900 & 1,900 & 1,900 \\
\hline
\end{tabular}

SourcE.-This table is based on data from the 1997-98 PASEC survey for Madagascar. NoTE.-The figures in parentheses are the robust $t$-statistics.

${ }^{a}$ See $\mathrm{n} .15$ for an explanation of the construction of this index.

* Significant at the $5 \%$ level.

** Significant at the $1 \%$ level. 
TABLE 4

Private School Advantage in Test Scores over Public Schools, Madagascar, 1997-98 (Units of Standard Deviation from the Sample Mean)

\begin{tabular}{|c|c|c|}
\hline \multirow[b]{2}{*}{ Influence of Selection Bias } & \multicolumn{2}{|c|}{$\begin{array}{c}\text { Factors to Which Private School Advantage } \\
\text { Is Attributable }\end{array}$} \\
\hline & $\begin{array}{l}\text { Combined Influence of } \\
\text { All School Assets, } \\
\text { Tangible and Otherwise }\end{array}$ & $\begin{array}{l}\text { Better Management and } \\
\text { Other Intangible School } \\
\text { Assets }\end{array}$ \\
\hline \multicolumn{3}{|l|}{ Grade 2: } \\
\hline Included & .73 & \\
\hline Excluded & .04 & .02 \\
\hline \multicolumn{3}{|l|}{ Grade 5: } \\
\hline Included & .64 & \\
\hline Excluded & .26 & .40 \\
\hline
\end{tabular}

SourcE.-This table is based on the regression results reported in tables 2 and 3 .

Note.-The test scores are the combined results on the mathematics and French tests. The estimates in the "included" rows correspond to the "unconditional" private school advantage. As explained in the analytical framework, these estimates take into account only the impact of pupils' observed characteristics on test performance and ignore the impact of selection bias associated with school choice. The estimates in the "excluded" rows correspond to the "conditional" private school advantage in which the impact of observed and unobserved pupil characteristics are taken into account. All estimates are statistically significant at the $1 \%$ level.

a After controlling for the influence of pupils' personal and family background.

and class size also affect student achievement, both in the expected direction, whereas these factors hardly matter in the earlier grade.

\section{B. Public-Private Sector Differences in Learning Outcomes}

For both the second- and fifth-grade samples, the coefficients on the private school variable are consistently positive, suggesting that, all else being the same, pupils in private schools achieve better test scores. Three possible factors account for private schools' superior performance: ability to attract a preferred clientele (e.g., those who share certain values or characteristics, such as a stronger motivation to succeed academically, greater parental interest in the children's academic progress, etc.), better resource endowment, and greater efficiency in managing the available resources to enhance learning. What is the relative importance of these factors in producing the observed private school advantage?

To answer this question, we follow the method set forth in Section II and obtain the results presented in table 4. Consider first the estimates for the second-graders. After controlling for observed differences in pupils' personal and family characteristics, the average year-end test score in private schools exceeds that in public schools by 0.73 of a standard deviation from the sample mean, reflecting the combined influence of selection bias and the totality of school factors (i.e., including tangible and intangible assets such as management efficiency). ${ }^{17}$ That advantage shrinks to only 0.04 , however, once selection bias is taken into account, thus wiping out nearly $95 \%$ of the private 
school advantage. The advantage drops further to 0.02 after taking into account that private schools in the sample have a more generous endowment of tangible school inputs for second-grade instruction than their public school counterparts. Selection bias is therefore the overwhelming source of private schools' superior performance on the second-grade tests.

The results are quite different for the grade-5 sample. The starting gap (after controlling for observed differences in pupils' personal and socioeconomic background) is 0.64 of a standard deviation from the sample mean, again reflecting the combined influence of social selection and differences in school factors, tangible or otherwise. Allowing for selection bias reduces the private school advantage to 0.26 , a drop of $50 \%$ - much smaller than the corresponding drop in the grade- 2 sample. Private schools in the dataset have higher pupil-teacher ratios (46 as compared with 34 in public schools) and less experienced teachers (11 years on average as compared with 17 years), so after allowing for these handicaps and other differences in tangible school inputs, we find that, instead of shrinking, the private school advantage actually widens to 0.40 of a standard deviation above the sample mean. This result can be attributed to private schools' greater effectiveness in managing the pedagogical process. ${ }^{18}$ Thus, in contrast to the situation in second grade, the role of managerial efficiency becomes much more important in explaining fifth-graders' superior performance in private schools, even though social selection continues to play a substantial role.

Taken together, the findings described above lend themselves to the conclusion that private schools can and do indeed select pupils with preferred profiles, and this advantage is one reason why private school students obtain better test scores. Yet this factor alone cannot fully account for better outcomes in private schools, especially in the upper grades, for which the cumulative influence of better management of the pedagogical process might be expected to, and does indeed, manifest itself.

\section{A Closer Look at Performance within the Public Sector}

In light of the findings, it is appropriate to ask how public schools can become more efficient in the delivery of services. Our analysis focuses on the public schools in the 1997-98 PASEC survey, and we enriched the dataset by merging it with the 1997-98 school census. Particularly important information in the school census includes the staffing profile of each school and the distribution of teachers and other school personnel across salary grades-information that makes it possible to compute the salary bill for each school and, hence, the per-pupil salary cost. The resulting dataset provides a basis for assessing the relation between school-level student achievement (controlled for students' personal and family characteristics at each school) and funding levels and other characteristics of the schools. ${ }^{19}$

The regression results appear in table A2. Consistent with earlier results, they suggest that access to textbooks and spending per pupil are among the policy-sensitive variables that affect student learning in public schools. The 
impact of textbook availability is substantial: among fifth-graders, for example, all else being the same, those supplied with books pull ahead in test scores by an average of about one-quarter of a standard deviation, a gain that is about twice as large as that reported in the earlier analysis based on the combined data for public and private schools. The magnitude of public spending per pupil is much more modest: all else being the same, a doubling of spending from the sample average of FMG 150,000 per pupil improves yearend test scores by no more than one-seventh of a standard deviation. The finding implies that targeted spending on specific school inputs with a widely documented track record in improving student achievement (in this case textbooks) is likely to be more effective in raising test scores than a generalized increased in spending.

Using the regression results, we can simulate the relation between perpupil spending and year-end test scores with schools instead of individual pupils as the unit of observation. The results appear in figure 1, in which each small circle represents a school. The $x$-axis shows the average per-pupil spending on personnel at each school, and the $y$-axis shows the school-level average in year-end test scores after standardizing the scores for pupils' personal and family characteristics. ${ }^{20}$ Figure 1 suggests that, while better endowed schools tend, on average, to deliver better outcomes, there is a huge range of outcomes across similarly endowed schools, which confirms the weak link between spending and outcomes discussed above. Further, we can trace out a so-called empirical production frontier that identifies schools with the best results for given levels of spending. ${ }^{21}$ In both samples, the "frontier" shows a familiar shape, with performance rising with spending and then leveling off (or even falling off) after some point.

The large disparities in performance across schools and the fact that so many schools lie well inside the frontier are telltale signs of weak management in terms not only of resource allocation but also pedagogical processes inside the "black box" of individual schools and classrooms. The problem is not unique to Madagascar, as the large literature on school management attests. Governments in many parts of the developing world struggle with it, and many have responded with reforms, particularly by decentralizing decision making and education finance in the expectation that greater school autonomy and community participation in the life of schools would bring about better results. ${ }^{22}$ In Madagascar, the government has likewise put in place mechanisms for decentralized school management, including the use of contrats programmes to formalize the mutual accountability of the three key parties involved (i.e., the government, parents, and the management and staff of individual schools) with regard to both resource mobilization and school performance. In addition, the government has taken steps to decentralize spending authority to lower levels, a process that is likely to be reinforced in the context of the 1998 constitutional reforms that paved the way for the election of provincial governors at the end of 2000.

Critically important to the success of decentralized school management 

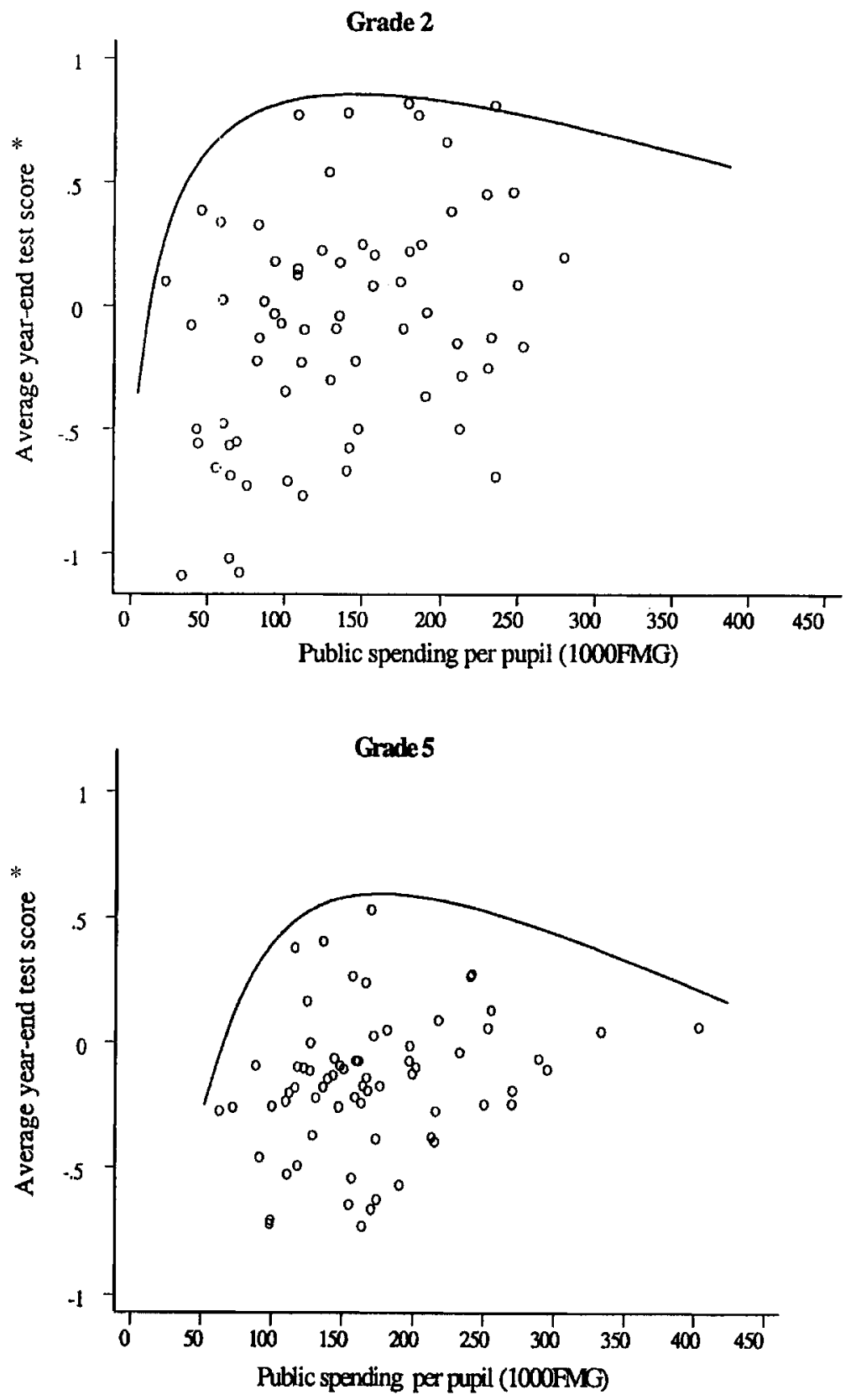

FIG. 1.- Relation between per pupil spending and test scores across public schools, Madagascar, 1997-98. * School-level average predicted from the regression estimates reported in table A1 at the sample means pupils' personal and family characteristics as well as initial test scores. 
is how it transforms educational practices at the level of individual schools and classrooms. In summarizing the experience in Latin American countries where reform has proceeded apace during the 1980s and 1990s, P. Dalin and others suggest that, while the availability of good teaching materials is important, it is insufficient for success in the absence of teacher mastery of the materials and the skills to communicate them. ${ }^{23}$ Such mastery is best developed through systematic and sustained local learning, including through in-service training, supervision, and coaching in a collegial atmosphere. In Madagascar, the isolation and inaccessibility of the many small schools that make up the education system clearly hampers the provision of the needed support. While priorities will need to be set on how best to deploy the country's scarce financial and human resources, any measure to stimulate school improvements would probably call for a two-pronged effort aimed at equipping teachers and school administrators to do a better job (such as through demonstrably effective in-service training and professional development programs) and providing teachers and other school personnel appropriate incentives to deliver. These interventions appear especially pertinent for the lagging schools identified in figure 1 .

\section{Conclusion}

Our results suggest that private schools are generally more efficient than public schools in the sense that a student with a given set of personal characteristics who attends a private school would obtain a higher score than he or she would in a public school with the same level of inputs. Furthermore, within the public system, some schools are more efficient than others, as evidenced by the lack of a strong relation between funding and learning outcomes across schools. The result implies that schools probably differ widely in how they are run, for example, in terms of how teachers use their instructional time and manage their classes and how their supervisors guide, monitor, and evaluate their work. ${ }^{24}$

One possible source of private schools' generally superior outcomes is that they tend to be more closely supervised, and, indeed, operate in a structure that demands that school managers demonstrate greater accountability and responsiveness to fee-paying parents. ${ }^{25}$ The public system may not be able to replicate exactly the same incentive structures, but it can develop strategies for better management of the system and stimulate more active engagement of local communities in schools. The existence of large disparities in learning outcomes across public schools that receive similar funding and that serve similar clienteles suggests that more can be done to target lagging schools for closer supervision. They also imply that, while lack of funding may constrain performance in some public schools, particularly in those where minimum conditions for learning are not met, an infusion of additional spending would make sense only if accompanied by concurrent measures to improve the management of pedagogical processes operating at the level of schools 
and classrooms and to ensure that the resources made available to the schools are effectively transformed into student learning.

With regard to community participation, recent innovations by the government to encourage greater local participation in school management could also provide part of the missing ingredient by increasing local monitoring of school performance. The arrangements are still too new for their effectiveness to be evaluated, but the authorities could nonetheless learn from the experience of other countries with more mature processes. ${ }^{26}$ That experience suggests that, when education decentralization is properly managed and focused on school-level autonomy and accountability, it could be a catalyst for improved school effectiveness. The challenge for Madagascar is to adapt those experiences to its own social and institutional context so that the productivity of the country's investment in education can be maximized.

\section{Appendix}

\section{TABLE A1}

Probit Estimates of a Child’s Probability of Attending a Private School

\begin{tabular}{|c|c|c|c|c|}
\hline \multirow[b]{2}{*}{ Characteristic } & \multicolumn{2}{|c|}{ GRADE 2} & \multicolumn{2}{|c|}{ GRADE 5} \\
\hline & Coefficient & $t$-Statistic & Coefficient & $t$-Statistic \\
\hline Intercept & -2.980 & 6.63 & -.431 & .80 \\
\hline Child is a girl & .050 & .73 & -.034 & .49 \\
\hline Child's age in years & -.248 & 9.85 & -.234 & 10.04 \\
\hline Child lives with parents & .140 & 1.44 & -.124 & 1.24 \\
\hline Index of family wealth ${ }^{\mathrm{a}}$ & .036 & 9.86 & .021 & 5.20 \\
\hline $\begin{array}{l}\text { Private sector share of schools } \\
\text { in child's home district }(\%)^{\mathrm{b}}\end{array}$ & .014 & 10.30 & .015 & 10.72 \\
\hline Pseudo $R^{2}$ & .199 & & .169 & \\
\hline Likelihood ratio $\chi^{2}($ d.f. $=5)$ & 429.42 & & 349.72 & \\
\hline$N$ & 1,993 & & 1,900 & \\
\hline
\end{tabular}

Source. - This table is based on data from the 1999 PASEC survey for Madagascar.

${ }^{a}$ See n. 14 for an explanation of the construction of this index.

b District refers to "firaisana." 
TABLE A2

Correlates of Second- and Fifth-Graders' Combined Scores in Mathematics and French in Public Schools

\begin{tabular}{|c|c|c|c|c|}
\hline \multirow[b]{2}{*}{ ChaRACTERISTIC } & \multicolumn{2}{|c|}{ GRADE 2} & \multicolumn{2}{|c|}{ GRADE 5} \\
\hline & Model 1 & Model 2 & Model 1 & Model 2 \\
\hline Intercept & $\begin{array}{l}-1.209 \\
(3.35)^{* *}\end{array}$ & $\begin{array}{l}-1.976 \\
(4.86)^{* *}\end{array}$ & $\begin{array}{r}.517 \\
(1.17)\end{array}$ & $\begin{array}{l}.187 \\
(.41)\end{array}$ \\
\hline Incoming test score & $\begin{array}{c}.553 \\
(22.75)^{* *}\end{array}$ & $\begin{array}{c}.561 \\
(22.65)^{* *}\end{array}$ & $\begin{array}{c}.335 \\
(11.15)^{* *}\end{array}$ & $\begin{array}{c}.344 \\
(11.36)^{* *}\end{array}$ \\
\hline Girl & $\begin{array}{r}.086 \\
(1.78)\end{array}$ & $\begin{array}{r}.084 \\
(1.74)\end{array}$ & $\begin{array}{c}.128 \\
(2.56)^{*}\end{array}$ & $\begin{array}{c}.126 \\
(2.54)^{*}\end{array}$ \\
\hline Age (in years) & $\begin{array}{c}.046 \\
(2.16)^{*}\end{array}$ & $\begin{array}{c}.050 \\
(2.32)^{*}\end{array}$ & $\begin{array}{l}-.106 \\
(4.50)^{* *}\end{array}$ & $\begin{array}{l}-.088 \\
(3.64)^{* *}\end{array}$ \\
\hline Repeater & $\begin{array}{l}-.091 \\
(1.79)\end{array}$ & $\begin{array}{l}-.082 \\
(1.63)\end{array}$ & $\begin{array}{r}-.037 \\
(.66)\end{array}$ & $\begin{array}{c}-.036 \\
(.65)\end{array}$ \\
\hline $\begin{array}{l}\text { Pupil speaks only Malagasy } \\
\text { at home }\end{array}$ & $\begin{array}{r}-.067 \\
(.75)\end{array}$ & $\begin{array}{r}-.065 \\
(.73)\end{array}$ & $\begin{array}{l}-.161 \\
(1.82)\end{array}$ & $\begin{array}{l}-.159 \\
(1.80)\end{array}$ \\
\hline $\begin{array}{l}\text { Pupil receives help from par- } \\
\text { ents for homework }\end{array}$ & $\begin{array}{l}.019 \\
(.33)\end{array}$ & $\begin{array}{l}.026 \\
(.45)\end{array}$ & $\begin{array}{r}.062 \\
(1.25)\end{array}$ & $\begin{array}{r}.050 \\
(1.02)\end{array}$ \\
\hline $\begin{array}{l}\text { Pupil has math or reading } \\
\text { textbook }\end{array}$ & $\begin{aligned} .108 \\
(1.91)\end{aligned}$ & $\begin{array}{c}.126 \\
(2.20)^{*}\end{array}$ & $\begin{array}{c}.271 \\
(4.41)^{* *}\end{array}$ & $\begin{array}{c}.245 \\
(3.94)^{* *}\end{array}$ \\
\hline $\begin{array}{l}\text { Public spending per pupil (in } \\
1,000 \mathrm{FMG})^{\mathrm{a}}\end{array}$ & $\begin{array}{c}.001 \\
(2.42)^{*}\end{array}$ & & $\begin{array}{c}.001 \\
(3.11)^{* *}\end{array}$ & \\
\hline Class size & & $\begin{aligned}-.000 \\
(.757)\end{aligned}$ & & $\begin{array}{l}-.005 \\
(2.72)^{* *}\end{array}$ \\
\hline Teacher experience (in years) & & $\begin{array}{l}.006 \\
(1.71)\end{array}$ & & $\begin{array}{r}-.003 \\
(.75)\end{array}$ \\
\hline $\begin{array}{l}\text { Initial training of teacher (in } \\
\text { years) }\end{array}$ & & $\begin{array}{c}.071 \\
(4.45)^{* *}\end{array}$ & & $\begin{array}{c}.070 \\
(4.80)^{* *}\end{array}$ \\
\hline $\begin{array}{l}\text { Preservice training of teacher } \\
\quad \text { (in months) }\end{array}$ & & $\begin{array}{l}-.016 \\
(3.38)^{* *}\end{array}$ & & $\begin{array}{c}.014 \\
(2.12)^{*}\end{array}$ \\
\hline $\begin{array}{l}\text { Index of classroom } \\
\text { conditions } s^{\mathrm{b}}\end{array}$ & $\begin{array}{r}.004 \\
(1.63)\end{array}$ & $\begin{array}{r}.005 \\
(1.85)\end{array}$ & $\begin{array}{r}.004 \\
(1.63)\end{array}$ & $\begin{array}{l}.000 \\
(.21)\end{array}$ \\
\hline$\lambda$ & $\begin{array}{c}.285 \\
(2.19)^{*}\end{array}$ & $\begin{array}{c}.394 \\
(3.15)^{* *}\end{array}$ & $\begin{array}{l}-.547 \\
(3.57) * *\end{array}$ & $\begin{array}{l}-.350 \\
(2.35)^{* *}\end{array}$ \\
\hline$R^{2}$ & .34 & .35 & .21 & .22 \\
\hline$N$ & 1,164 & 1,164 & 1,205 & 1,205 \\
\hline
\end{tabular}

Source. - This table is based on data from the 1997-98 PASEC survey for Madagascar.

NoTE. $-t$-statistics are in parentheses.

a Public spending per pupil is computed by averaging the specific classroom teacher's salary plus benefits over the number of pupils in the class and adding the total cost of other personnel at the school divided by the number of pupils in the school.

${ }^{\mathrm{b}}$ See $\mathrm{n} .15$ for an explanation of the construction of this index.

* Significant at the 5\% level.

** Significant at the $1 \%$ level. 


\section{Notes}

1. For these and other data on the overall features of the education system, see World Bank, Education in Madagascar: Policy Directions for the Next Decade (Washington, D.C.: World Bank, 2001).

2. UNESCO, "With Africa for Africa: Towards Quality Education for All," Draft Regional Report, Education for All-2000 Assessment Survey, 1999 MLA Project (Human Sciences Research Council, Pretoria, 1999).

3. Programme d'Analyse des Systèmes Educatifs de la CONFEMEN (PASEC), Les facteurs de l'efficacité dans l'enseignement primaire: Données et résultats sur cinq pays d'Afrique et de l'Océan Indien (Efficiency in primary education: Data and results from five countries across Africa and the Indian Ocean) (Dakar: Conférence des Ministres de l'Education des Pays Ayant le Français en Partage [CONFEMEN], 1999).

4. See, e.g., E. Jimenez, M. Lockheed, E. Luna, and V. Paqueo, "School Effects and Costs for Private and Public Schools in the Dominican Republic," International Journal of Educational Research 15 (1991): 393-410; E. Jimenez, M. Lockheed, and V. Paqueo, "The Relative Efficiency of Private and Public Schools in Developing Countries," World Bank Research Observer 6 (1991): 205-18; E. Jimenez, M. Lockheed, and N. Wattanawaha, "The Relative Efficiency of Private and Public Schools: The Case of Thailand," World Bank Economic Review 2 (1988): 139-63; G. Lassibille and J. P. Tan, "Are Private Schools More Efficient than Public Schools? Evidence from Tanzania," Education Economics 9 (2001): 145-72; G. Psacharopoulos, "Public versus Private Schools in Developing Countries: Evidence from Colombia and Tanzania," International Journal of Educational Development 17 (1987): 59-67.

5. See, e.g., E. Hanushek, "The Economics of Schooling: Production and Efficiency in the Public Schools," Journal of Economic Literature 25 (1986): 1141-77; L. J. Lau, "Educational Production Functions," in Economic Dimensions of Education, ed. D. M. Windham (Washington, D.C.: National Academy of Education, 1979), pp. $28-53$.

6. In our empirical analysis, we use the Chow test to confirm that it is appropriate to specify a single regression model instead of separate regressions for public and private schools.

7. See, e.g., G. S. Maddala, Limited Dependent and Qualitative Variables in Econometrics (Cambridge: Cambridge University Press, 1983); W. Greene, Econometric Analysis, 3d ed. (London: Prentice-Hall International, 1997); F. Vella, "Estimating Models with Sample Selection Bias: A Survey," Journal of Human Resources 33 (1998): 127-69. Also see J. Heckman, "Sample Selection Bias as a Specification Error," Econometrica 47, no. 1 (1979): 153-61.

8. As indicated above, the achievement regression in our analysis involves yearend test scores as the dependent variable and incoming test scores as one argument in the vector $\boldsymbol{X}$. Under this specification, the coefficient estimate on the incoming test score may be biased because of its possible correlation with socioeconomic background and schooling inputs in the current school year. Correlation with schooling inputs is highly unlikely, however, except in the rare case where a teacher teaches the same sample pupils over the course of 2 consecutive school years. With regard to the correlation with socioeconomic background, one solution is to transform the regression equation by using the difference between the scores in the two grades as the regressor rather than placing them on different sides of the equation. The procedure is inappropriate, however, for two reasons: the scores are based on different tests, making it impossible to recalibrate them to perform meaningful arithmetical operations between them, and the implied assumption of a one-to-one relation between scores on the two tests is also unlikely to be valid. While recognizing that the value-added model spec- 
ification is not flawless, we nonetheless note that the approach is consistent with common practice in the literature. See, e.g., Hanushek or Lau.

9. H. Leibenstein, "Allocative Efficiency vs. X-Efficiency," American Economic Review 56 (1966): 392-415.

10. A more detailed description of the survey can be found at the Web site of the Conférence de Ministres de l'Education des Pays Ayant le Français en Partage (CONFEMEN), which was created by le Centre International pour le Développement de l' Inforoute en Français (CIDIF), http://www.confemen.org/pasec, last accessed February 18, 2003.

11. Data relating to private schools probably suffer from greater measurement errors than those for public schools, implying that the regression coefficients for private schools are subject to larger biases than those for public schools.

12. See, e.g., Greene. To save space, the coefficients of the dummy variables for missing observations are not shown in the regression results.

13. To facilitate interpretation of the results, students' test scores are expressed in units of standard deviation from the mean in our analysis. Because of our interest in overall performance, we focused on students' average scores on the two main subjects (French and mathematics) rather than on each subject separately. The results based on the combined scores are consistent with those based on separate regressions for the two subjects. While space constraints prevent reporting the regressions here, they are available upon request from the authors.

14. The wealth index is constructed using principal components analysis. For details, see D. Filmer and L. Pritchet, Estimating Wealth Effects without Expenditure Data-or Tears: An Application to Educational Enrollment in States of India (Washington, D.C.: World Bank, 1998). It is based on a family's ownership of the following assets: armchair, refrigerator, tap, electricity, car, bike, moped, video, TV, radio, gas stove, and in-house toilet. The index ranges from around 133 for a family who owns all the items to around 90 for a family who owns none of them.

15. This index is constructed using principal components analysis based on the following physical conditions of the classroom: the permanence of the structure; the availability of electricity; and whether the room is equipped with a cupboard, chairs and tables for all pupils, rulers, set squares, compasses, a dictionary, and maps of Madagascar, Africa, and the world. The index ranges from about 116 in classrooms with all these features to 83 in those with none of them.

16. The available data contain no information on some of the key factors that other researchers (e.g., P. Glewwe and H. Jacoby, "Student Achievement and Schooling in Low-Income Countries: Evidence from Ghana," Journal of Human Resources 29 [1994]: 843-64; H. Lankford and J. Wyckoff, "Primary and Secondary School Choice among Public and Religious Alternatives," Economics of Education Review 11 [1992]: 317-37) have found to be important in affecting school-choice decisions, including such variables as household composition, parents' religious and political affiliations, residential location, relative cost of different schools and their quality, etc. Given this limitation in the data, our results preclude firm conclusions as to how families actually choose among school alternatives. Following other studies that suffer from similar data problems (e.g., those by Jimenez et al.; Jimenez, Lockheed, and Wattanawaha; Lassibille and Tan [all at n. 4 above]), we merely use the results of our school choice model to correct for possible biases in estimating the achievement equation.

17. Note that 0.73 corresponds exactly to the coefficient estimate on the private school variable in the regression controlled for selectivity.

18. Because of data limitations and a desire for parsimony in model specification, the regression contains only the key variables describing the schools and classrooms. The effect of differences in endowments, which are not included in the model, are therefore captured in what appears under the label of differences in efficiency.

19. Spending on other inputs is not separately available, so our analysis used an 
index of the material condition of the classroom context as a proxy for this aspect of school inputs. The school census does not detail the salary grade of private-sector personnel.

20. The figure is based on the regression estimates reported in table A2. For each school in the sample, the average year-end test score is predicted by evaluating the regression equation at the sample means of all the regressors except public spending per pupil, which is school specific. The predicted test score is then plotted against the latter variable.

21. In theory, it is possible that public schools located near the "frontier" are able to perform well because of competition from effective schools in the same area. If so, the "frontier" may not necessarily be attainable for public schools operating in other settings. In the Malagasy context, however, most public schools operate in rural areas while private schools are found almost exclusively in the urban areas. It thus remains valid to suggest that the wide scatter of schools in the figure points to substantial inefficiencies in school management in the public sector.

22. See, e.g., D. Winkler and A. I. Gershberg, "Education Decentralization in Latin America: The Effects on the Quality of Schooling," LCSHD Paper Series no. 59 (World Bank, Washington, D.C., 2000); E. King and P. Orazem, "Evaluating Education Reforms: Four Cases in Developing Countries," World Bank Economic Review 13 (1999): 409-14.

23. P. Dalin, T. Ayono, A. Biazen, B. Dibaba, M. Jahan, M. B. Miles, and C. Rojas, How Schools Improve: An International Report (New York: Cassell, 1994).

24. World Bank (n. 1 above).

25. See, e.g., E. Jimenez and V. Paqueo, "Do Local Contributions Affect the Efficiency of Public Primary Schools?" Economics of Education Review 15 (1993): 377-87; D. R. Winkler and T. Rounds, "Municipal and Private Sector Response to Decentralization and School Choice," Economics of Education Review 15 (1993): 365-86; C. M. Hoxby, "Do Private Schools Provide Competition for Public Schools?" NBER Working Paper no. 4978 (National Bureau of Economic Research, Cambridge, Mass., 1994).

26. See, e.g., Winkler and Gershberg. 